\title{
The role of religious architecture in the sustainable development of contemporary cities: traditions and innovations
}

\author{
Igor' Pryadko * and Dar'ja Belinskaya
}

Moscow State University of Civil Engineering, Yaroslavskoe shosse, 26, Moscow, 129337, Russia

\begin{abstract}
The novelty of this paper resides in the fact that its co-authors analyze processes of urban formation and architectural development from the perspective of the city's performance of social functions. The coauthors study religion as a social institution and the role that it plays in the emergence of medieval cities and in the arrangement of external and internal environments of human beings in present-day cities. Their role is determined as innovative. The performance by the institution of religion of its historic function is studied from the standpoint of the concept of sustainable development. The methodology of this research project is based on the retrospective analysis of historical documents, the comparative analysis of built-up areas, housing planning in traditional and contemporary societies, and the systems concept. As a result of this research, the co-authors have successfully identified several features typical for the operation of the institution of church in a medieval city. The co-authors have analyzed the way the Christian ideology determines the interior and the architectural landscape. The co-authors outline the areas for the application of their research findings. The co-authors believe that these findings must be taken account of in the course of restoration performed in a contemporary megalopolis and in the process of study of the history of urban settlements.
\end{abstract}

\section{Introduction}

Any city has a multi-layered and multi-aspect structure; therefore, sustainable development is only possible in urban areas, if multiple factors are taken account of. These factors comprise religious and ethno-cultural components. During the periods of Late Antiquity and Middle Ages, the Christian Church as an institution influenced the process of urban development. It has retained this function to some extent.

It is noteworthy that many cultural property sites represent temple complexes, monasteries and convents, chapels and other houses of worship, and here arises the issue of the legal framework for their protection, operation, and restoration, as well as their funding. Russia passed the Federal Law "On Items of Cultural Legacy (Monuments of History and Culture) of the Peoples of the Russian Federation" (of June 25, 2002 No. 73-FZ), amended

*Corresponding author: Priadcko.igor2011@yandex.ru 
on December 29, 2017 [1]. Thanks to this law, church buildings have preserved their social and "space forming" functions. In this article, the co-authors' intent is to identify the correlation between traditions and innovations in the architectural space of contemporary cities. The co-authors will analyze the issues of innovative dynamics, associated with the understanding of the choice of sites selected for the construction of temples in megalopolises. The co-authors will also shed light on the reasons why items of religious architecture need protection and restoration.

Temples and places of public worship represent two most numerous categories of listed monuments of architectural heritage. Therefore, here the co-authors will analyze houses of worship as one category. The co-authors will analyze the role and place of the monuments of religious culture in the urban architectural space.

Historically, religion as a social institution has been solving urban planning problems. Practical architecture performs social functions, including the one of urban planning. A high-quality urban living environment offers accessible high-quality social services. And they contemplate the exercise of the constitutional rights to freedom of conscience and religion, municipal services, etc. Moreover, irrespective of religious beliefs, state residents have the right to know the history of their country; they must be privy to the past of their ethnicity; they must know the origin of their beliefs and the mindset of their ancestors. Today it's not easy to satisfy religious needs, as the $21^{\text {st }}$ century city became multiconfessional a while ago. Hence, there arises the following problem: how can a city balance innovations with traditional urban lifestyle in a contemporary megalopolis? How can religious needs of each resident be satisfied? Since the days when European cities were founded and up to the present moment, temple complexes and grand cathedrals, buildings of monasteries and convents have been serving as dominant urban elements. Even today they dominate the way these cities look. That's the reason why the original exterior of St. Peter's Basilica is preserved so carefully in Rome, the same about St. Paul's Cathedral, designed by C. Wren, a famous British architect and mathematician, and S. Isaak's Cathedral in St. Petersburg, that immortalized the name of Auguste Ricard de Monferrand. Further we are going to analyze the role of religion as an institution in the formation of cities and the actions to be taken by legislators and restorers for this function to be preserved.

\section{Materials and methods}

In this article, the co-authors analyze the influence produced by the religious tradition on the architectural environment in the cities of Europe. At the same time, the co-authors solve the problem of correlation between traditions and innovations in the urban architectural environment. The co-authors have tracked the link between old residential houses in European capitals and their contemporary development patterns. The goals to be sought have determined the set of methods to be employed. They include the retrospective analysis of legal sources, the general method of deduction, the inference by analogy, and the comparative historical approach. In particular, the material under research includes regulatory acts, federal laws and subordinate legislation, namely, resolutions issued by the executive authorities in respect of protection and restoration of the cultural heritage. When addressing principles of medieval urban development (as the majority of items of cultural heritage date back to this period of Russian history), the co-authors cite Domostroy written in the $16^{\text {th }}$ century. This book offers recommendations concerning the interior of an Orthodox residence. [2] Extracts from this Old Russian book are reproduced in this article in the simplified manner: they miss diacritical marks, tildes and "yuses", the "yat" letter is replaced by "e", "izhitsa" and "decimal e" are replaced by "octonary e". Old Church Slavonic numeration is replaced by modern figures. 
As for the analysis, applied in this article, it is noteworthy that the co-authors do not consider any differences between Eastern and Western religious worldviews, practical architecture, urban planning and restoration (although these differences are, definitely, significant). In this work, the co-authors make an attempt to interpret social practices from the perspective of specific worldviews and the idea of their unity in the Christian culture. Dissimilarities in the perception of the urban space in the West and East of the Christian worlds may be the subject of a different research, while in this work we address general aspects of urban planning, namely, construction techniques and technologies, within the framework of one single Christian Universe.

\section{Results}

In this section we are going to identify the properties of a European city that are determined by the public consciousness traditional for this continent. It is noteworthy that the structure of a typical Christian settlement contemplates rigorous separation of space, its "hierarchization" in respect of family life and indoor interiors. Traditional residential houses of Western and Eastern Europe feature parts of houses reserved for men and women, as well as one room, used both by male and female folks. Each household has a "beautiful corner" for icons, the veneration of which was made obligatory at the $7^{\text {th }}$ Ecumenical Council. [3] This architectural planning pattern fits the Christian idea of the world order, resting on the following ternary oppositions, including:

the future - the present - the past;

the facial image - the face - the guise [4];

male - neuter - female;

heavenly - human - devilish [5, 6], etc.

In a Christian house, the dining room served as a living room; it was not only the space designated for eating together with the folks, it was also the place for a family prayer, family festivities and other memorable events. The contemporary author attempted to reflect upon the ancient and traditional attitude towards urban lifestyles and their patterns. In his essays on folk life he wrote: "Any good life is full of harmony, positive attitude and rhythm, consistency and diversity. This life is full of organic interrelations between all events". [7] Any residence must be filled with harmony and tranquility.

The modern age has preserved the rhythm in the arrangement of interiors. We can use the designs, performed by Auguste Ricard de Monferrand, the architect of S. Isaak's Cathedral in St. Petersburg, to substantiate our statement. [8]

Let's address another aspect of the problem in question. In the early $21^{\text {st }}$ century, multilevel (federal and regional) legislative authorities were to meet the top-priority challenge that consisted in the preservation and restoration of historic and cultural heritages. The problem arises when the needs of the city are to be reconciled with the demands of its social groups: on the one hand, historic buildings must be preserved, and on the other hand, day-to-day wants of urban residents require attention and the urban economy needs development. Some specialists believe that problems of restoration and protection of the cultural heritage "must be broken down into specific tasks and adjusted to problems of territories." [9] Any actions aimed at the protection of cultural property sites need to be reconciled with, for example, norms of the land legislation, safety requirements, and the needs of low-mobile urban residents. A comprehensive approach, implemented in 
some disciplines dealing with restoration must also be applied in the course of reconstruction of pieces of architecture. We believe that this is the key to sustainable urban development.

The requirements that the Christian tradition applied to the design and development of residential houses were implemented in numerous "manuals", "instructions", and "Specula", issued in the Middle Ages and on the eve of the modern age. Specula represent detailed codes, containing rules of conduct for urban and rural residents, instructions for the upbringing of children, standards of the day-to-day life, urban economy and personal households, personal environment developed for an affluent family, etc. Domostroy is the most famous book of instructions of this kind. It was edited by Archpriest Silvestr, an ally of Ivan the Terrible and Beneficiary of the Annunciation Cathedral. The third part of this book deals with the interior of residential houses. Particular attention is drawn to the interior design, disposition of rooms, items of furniture, trunks, houseware, and icons. Indeed, the author puts an equality sign between the church as a house of worship (that reads as "khram" in Russian) and a residential building (that reads as "khramina" in Russian). This "religious" parallel was developed by Vassily Belov, a Russian writer of the $20^{\text {th }}$ century, in his book "Harmony. Sketches of the Folk Aesthetics": "Construction of residential houses has something to do with icon painting. The art of a painter and a woodworker have nurtured the Russian culture since ancient times. There are no similar icons having the same design, although each icon must contain particular obligatory features. And the same about the houses." [7] And now let's get back to the instructions issued in the 16the century.

According to Archpriest Silvestr, icon worshipping brings domestic order, preserves multilevel social relations, and consolidates intra-familial links. "Icons should be placed at the entrance and positioned according to their importance... they should be mentioned in prayers." [2] In chapter 38, the author writes about good housekeeping and the woman of the house who is responsible for it.

The church is particularly important for the architectural urban environment. The church is the architectural structure that domineers over the environment. A traditional Christian church, having two apses [10], was initially constructed in the western areas of Germany, and later its design was adopted by western Christianity as the "centre of gravity" for local residents. A different architectural tradition developed in Eastern Europe, it was embodied in cross-building churches of the Byzantine style.

Let's focus on the social functions of houses of worship. Apart from serving as the places for religious services and other ceremonies, churches were the best locations for deal making, delivery of vital announcements and storage of urban treasuries. For example, in the Cathedral of St. Sophia in Novgorod, which is a former associated member of the Hanseatic League, the texts of the "Yaroslavl Pravda", the prototype of the urban constitution, were stored. [11] The sites selected to accommodate monasteries, which later turned into centres of urban settlements, were particularly beautiful and convenient. The architects, responsible for the design of houses of worship, had a thorough understanding of the composition and the commesurability of man-made structures and their natural environment. The $21^{\text {st }}$-century science, focused on innovations, has developed the notion of biosphere compatibility which was typical for medieval architecture. One German art and culture expert of the $20^{\text {th }}$ century ties this compatibility with the pre-Christianian period in history: "The religious architecture of the ancient world, if taken as a whole, represents a combination of enormous efforts of the humankind, aimed at the implementation of the most complex cosmic intuitions into sensory images." [12]

It is noteworthy that the Christian church has traditionally assumed the role of the institution that facilitates the advancement and innovative development of cities. Urban 
residents adopted Christianity earlier than rural residents, who remained pagans for a longer period of time. Christianity gained in popularity in the cities, and adherents of polytheism, or members of the rural community (or "pag" in Russian) were called "pogany", or "evil people". Later this term applied to all pagans. The French representative of the Annales school of history wrote: "Being a primarily urban religion, Christianity supported urban life in the West. And even if Episcopal cities preserved their economic function, it was the very primitive function that worked for the benefit of the barns owned by the bishop or the urban monastery, as the crop of the local community was transported there, and from there food was distributed between some residents for money and for free, in case of famine." [10] The economy of medieval settlements was based both on accumulation and production hidden behind the walls of monasteries. The conclusions made by the medieval philosopher are complemented by the present-day researcher: "There is no doubt that since early middle ages, rational economy and new inventions have been able to make their way in monasteries faster than anywhere else." [13] This process boosted urbanization, sustainable development of urban trading quarters, industrial urban areas, whose residents were released from taxes. [13] According to our contemporary, "stone architecture is associated with serfdom and urban monastery construction processes." [7]

Let's consider these statements in more detail. In the days of feudal disunity, new urban settlements were founded close to the fortresses owned by feudal lords and monasteries. Rapid propagation of monasteries improved urban life. In Eastern and Western Europe, monks were part of urban life; they facilitated the advancement of knowledge, crafts and technologies. The monastery served as the instrument that helped the Christian civilization oust the earlier one. The earlier civilization was called "the civilization of life amid wastelands, forests and overgrown fields, the civilization of the rural society, hardly influenced by the monastery (or urban, the note is made by the co-author) culture." [14] The monasteries, governed by strict charters, grew in number: when any of them prospered, it founded another monastery. Anachorets found new locations for their spiritual endeavours. Sometimes feudal lords asked monks, residing in famous monasteries, to found another monastery in the places indicated by the lords. In the Middle Ages, monasteries performed numerous functions. Cenobitic monasteries served as places for prayers, schools, model farms, book storages, developers of art and crafts. [10] They introduced innovative methods into trades and agriculture, let alone the expansion of literacy and agricultural technologies. The plan of the St. Gallen monastery contained a future school for the laity, although the Synodus, held in Aachen in 817, requested that the institutions of this kind were closed. [10] Similar schools were established by churches and monasteries of Ancient Russia as early as in the 11 th century.

\section{Discussion. Conflict of interests}

Let's discuss the findings obtained as a result of the analysis of the sources, dealing with the influence produced by religious architecture on the formation of medieval and contemporary urban areas. The co-authors studied the medieval sources and works written by art and culture experts to make a conclusion that in the Christian countries religious architecture had boosted the development of cities, whereas the church as an institution had fostered the development of new trades and the urban economy as a whole. The faith that was typical for the Old World served as a condition for social innovations. Innovations never ran into conflict with the need to save environmental resources, and this idea complies with contemporary green building standards. Pieces of religious architecture can be treated as the man-made extension of the natural environment.

The scope of problems, raised in this work, receives contradictory assessments and may cause a conflict of interests: not every humanities scholars and key opinion leaders in 
Russia and in the West agree that manmade and natural environments are interdependent and that architecture is in harmony with Christian traditions and values. J. Brodsky, a Nobel prize winner, who scathingly ridiculed the attempts of medieval urban planners and architects of the modern age to strike a balance between man-made and natural environments, wrote: "Maybe even... the whole European culture with its cathedrals, Gothicism, baroque, rococo, cartouches, trinkets, pilasters, acanthuses is the craving of a monkey for the forest it lost forever." [15] However, few authors are that skeptical.

\section{Conclusions}

In this section we will summarize our analysis and outline the prospects for the future research project. And now we will offer several items of medieval architecture to illustrate our statements.

Items of religious architecture, same the institution of religion, played an essential role in the development of medieval cities in the West and East of Europe. According to the coauthors, medieval religious architecture had a social function, which was important for the well-being of a person or a social group. The set of its functions also included the esthetic one: as a rule, items of religious architecture accentuated their natural environment. Architectural historians have discovered beautiful landscapes surrounding old cities. The monasteries founded by St. Sergius of Radonezh were surrounded by beautiful natural sites, including Mountain Makovets close to the Radonezh forest, the Kirzhach river, on the bank of which St.Sergius of Radonezh, acting together with his follower Simon, founded the Monastery of Annunciation, the Golutvin peninsula in Kolomna, where Grigory, the follower of St. Sergius of Radonezh, founded the Old Golutvin Monastery (see Fig. 1), the Vysokaya mountain in Serpukhov, etc. [16]

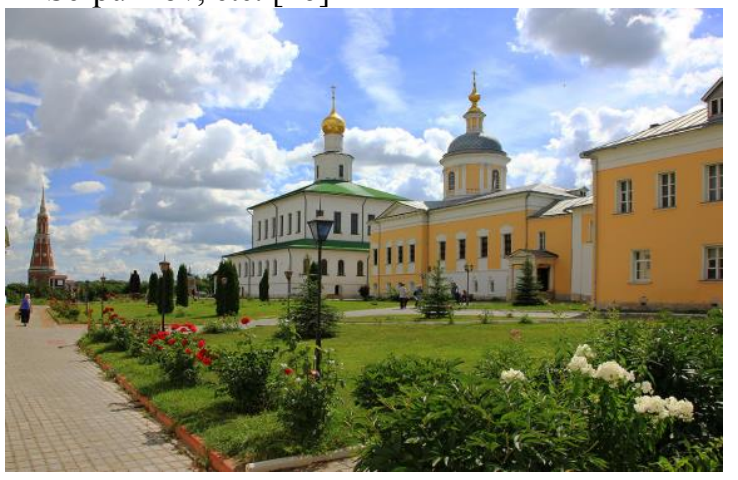

Fig. 1. Nowadays this active Old Golutvin monastery serves as the decoration of the Golden Ring.

"There is plenty of space, skies, clear airflows, water mirrors, blue forest valleys, free land full of ups and downs," exclaims our contemporary. [17] Another author points out the talent of medieval architects: "Probably, the sense of architectural proportion precedes the skill of calculating the height, width, length and dimensions, as well as lines and planes that correlate in the most harmonious way." [7]

Church buildings have preserved their architectural significance in the new age. Churches and chapels, sitting in gardens and parks, turned the capitals of Europe into green megalopolises. In his memoirs, N.P. Vishnyakov, a famous industrialist and philanthropist, called green Moscow yards "monasteries". The Church of Savior in Nalivki (See Figure 2) had "monasteries" of this kind around them, and the same about the church of Ivan the Warrior and other Moscow churches. [18] 


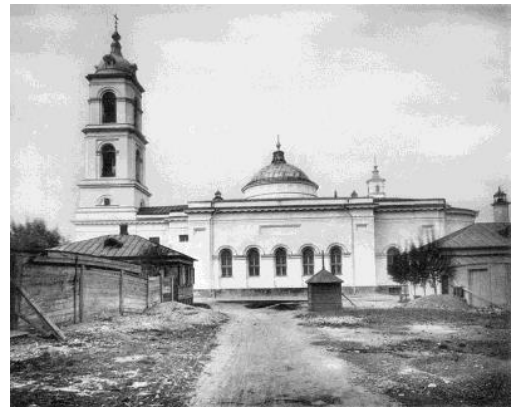

Fig. 2. The Church of Savior in Nalivki was demolished in 1929.

Urban planning principles, formulated by the Christian architecture in the Middle Ages, manifest themselves in contemporary cities and towns. No present-day buildings can hide the architectural framework designed by the founders of present-day settlements. In the context of deindustrialization, monasteries and church complexes regain their urban planning functions. They boost the development of the travel industry for urban residents to have more jobs and for urban budgets to generate higher revenues.

\section{References}

1. On the cultural heritage (monuments of history and culture) of the peoples of the Russian Federation. Federal Law No. 73-FZ of June 25, 2002 (amended on December 29, 2017) URL: https//www.consultant.ru/document/cons_doc_law_37318

2. N. Gudziy, A reader in ancient Russian literature (Moscow, Uchpedgiz, 1947)

3. A. Bronzov, John Damaskin. Three words to defend those who condemn holy icons (Sergiyev Posad, RFM, 1993)

4. P. Florensky, Iconostasis (Moscow, Iskusstvo, 1994)

5. L. Kovtun, V. Kolesova, Works of department of ancient Russian literature, 37, 392 (1983)

6. A. Belyakov, Herald of the Slavic University. 2, 11 (1997)

7. V. Belov, Harmony. Sketches of the Folk Aesthetics (Moscow, Molodaya Gvardiya, 1989)

8. V. Shuyskiy, The Artist, 12, 45 (1988)

9. O. Astafyeva, Journal of Culture Studies. 2, 73 (2011)

10. J. Le Goff, Civilization of medieval west (Moscow, Progress-Academy, 1992)

11. B. Rybakov, Kievan Rus and Russian princedoms of the $12^{\text {th }}-13^{\text {th }}$ centuries (Moscow, Nauka, 1993)

12. G. Vagner, Slovo. 7, 5(1991)

13. History of philosophy: West - Russia - East. Book 1 (Moscow, Greco - latin study, 1995)

14. O. Eger, Middle ages (St. Peterburg, Spec. literature, 1997)

15. V. Sirotin, North. 3-4, 34 (2007)

16. Monasteries founded by St. Sergius of Radonezh. URL: http:// pravoslavru.livejournal.com/5374730.html

17. Yu. Loschits, The Russian frontier. 1, 102 (1991)

18. N. Veshnaykov, Olden times in Moscow. Muscovites' memoirs about the past century. (Moscow, Pravda, 1989) 